\begin{tabular}{|c|l|}
\hline Title & Performance eval uation of hybrid treatment wetland for six years of operation in cold climate \\
\hline Author(s) & Harada, June; Inoue, Takashi; Kato, Kunihiko; U raie, Nana; Sakuragi, Hiroaki \\
\hline Citation & $\begin{array}{l}\text { Environmental science and pollution research, 22(17), 12861-12869 } \\
\text { https://doi.org/10.1007/s11356-014-3843-2 }\end{array}$ \\
\hline Issue Date & $2015-09$-30 \\
\hline Doc URL & http://hdl.handle.net/2115/62876 \\
\hline Type & article (author version) \\
\hline File Information & 71239 (井上京) .pdf \\
\hline
\end{tabular}

Instructions for use 


\title{
Performance Evaluation of Hybrid Treatment Wetland for Six Years of Operation in Cold Climate
}

\author{
June Harada ${ }^{\mathrm{a}}$ Takashi Inoue ${ }^{\mathrm{a}}$, Kunihiko Kato ${ }^{\mathrm{b}}$, Nana Uraie ${ }^{\mathrm{a}}$, Hiroaki \\ Sakuragi $^{\mathrm{a}}$
}

a Graduate School of Agriculture, Hokkaido University, N9W9, Kita-ku, Sapporo, Hokkaido, 060-8589, JAPAN (tino@env.agr.hokudai.ac.jp)

b NARO Tohoku Agricultural Research Center, Shimo-Kuriyagawa, Morioka, Iwate, 020-0198, JAPAN (katokuni@affrc.go.jp) 


\begin{abstract}
In Hokkaido, northern Japan, there are 12 hybrid subsurface constructed wetlands (HSCWs) and most of them are treating high concentrated organic wastewater. One of these systems is an HSCW situated in Embetsu, northern Hokkaido and it has been in operation since November of 2006 to treat dairy milking parlor wastewater. The system is composed of two vertical flow beds and a horizontal flow bed. The inflow and the outflow's flow rates and pollutant concentrations and loads were extremely variable. Throughout its six years of operation, most of the pollutant removals were decently high. Removal efficiencies for COD, $\mathrm{BOD}_{5}$ and SS were ranging in the $90 \%$. Removal efficiencies for $\mathrm{TN}, \mathrm{NH}_{4}-\mathrm{N}$, and $\mathrm{BOD}_{5}$ were improving because of the development of the soil ecosystem and the Phragmites australis community. However, the removal rates of TP were decreasing, presumably because of the declining adsorption ability. The accumulation of TP in the first and the second vertical beds had reached its plateau. Vertical beds had high removal efficiencies for TN, COD, $\mathrm{BOD}_{5}$ and SS. These high removal rates of the first vertical bed may be caused from the efficient removal of solid material that is deposited as an organic layer of the first vertical bed. High $\mathrm{NH}_{4}-\mathrm{N}$ removal rates exerted by the second vertical bed may be due to the recycling of wastewater. In conclusion, the HSCW was working excellently for its six years of operation, and it could be concluded that it has not reached its life yet.
\end{abstract}

Keywords: hybrid subsurface constructed wetland; non-domestic sewage; high organic matter; livestock industry; dairy milking parlor wastewater; long term monitoring

\title{
Introduction
}

Treatment wetlands are gaining popularity around the world. Their treatment potential is highly regarded because they could remove suspended solids (SS), total nitrogen (TN) and nitrogen compounds, total phosphorus (TP), pathogens, heavy metals and pharmaceuticals with low energy input (IWA 2000; Carvalho et al. 2013). The major benefits of these systems are their low operational and maintenance cost compared to conventional systems such as activated sludge. Out of many types of constructed wetland, hybrid subsurface constructed wetlands (HSCWs), a combination of vertical and horizontal subsurface flow constructed wetlands, are known for their high removal efficiencies. However, there are few constraints when using constructed wetlands in cold climates. These constraints arise mainly due to freezing of water, beds and distribution tubes during its winter months and decrease in microbial activity due to low temperature generally falling below $0^{\circ} \mathrm{C}$ (Kato et al. 2013). Thus the end product of this system has the risk to not satisfy the regulatory standards in harsh winter.

There are many examples where constructed wetlands were regarded as non-appropriate technology because its final effluent did not achieve regulatory standards (IWA 2000; Comino et al. 2011). Along with the climatic condition, there are also problems with the input load. It is safe to say that the technology is almost fully sophisticated in terms of municipal or domestic wastewater (Brix and Arias 2005a; Molle et al. 2005; Vymazal and Kröpfelová 2011). However, more data needs to be collected for constructed wetlands that are receiving high loads, such as dairy wastewater, to fully understand the potential of this technology because many of the research are based on short-term monitoring period (Comino et al. 2011; Comino et al. 2013; Mantovi et al. 2003; Reeb and Werckmann 2005). Long-term assessment should also be done to determine the removal efficiency during the start-up period, its maximum potential and when the treatment efficiency starts to degrade. These data are needed to determine the life of such system especially for phosphorus.

Today, increasing production of livestock is becoming a problem around the world due to their stress on public health and aquatic environment. Wastewater generated from livestock industries has many contaminants that have detrimental effects on the surrounding environment. Some of these contaminants include suspended solids (SS), biological oxygen demand $\left(\mathrm{BOD}_{5}\right)$, total nitrogen (TN), total phosphorus (TP), parasites, heavy metals and emergent contaminants such as pharmaceuticals (FAO 2006) and they are extremely concentrated. Nevertheless, the Japanese National Water Pollution Prevention Act are applicable only to facilities that are releasing more than $50 \mathrm{~m}^{3} /$ day, where most small scale livestock facilities are releasing less than that amount. However, there are many complaints filed against livestock farmers and $25.4 \%$ of this is due to water pollution (MAFF 2014). Thus farmers are required to find convenient methods to treat their wastewater.

In 2013, Hokkaido has 12 HSCWs and most of them are relatively new. Most systems treat concentrated wastewater like milking parlor wastewater, swine urine and effluent from a starch plant (Kato et al. 2013). Among them, the two oldest systems are systems that treat milking parlor wastewater 
and they have been operating for eight and seven years, respectively. Since there are only few HSCWs that treat high organic concentrated wastewater for a long period, it is important to evaluate such system in order to understand the potential life of HSCW. This paper investigates an HSCW that has been treating milking parlor wastewater since November of 2006.

\section{Background}

The research site is located in Embetsu, northern Hokkaido, Japan ( $\mathrm{N}^{\circ} 4^{\circ} 45.0^{\prime}$ latitude and E141 ${ }^{\circ} 48.4^{\prime}$ longitude). The average annual temperature is $6.4^{\circ} \mathrm{C}$ and the average annual precipitation is $1,053 \mathrm{~mm}$. This dairy farm keeps approximately120 dairy cows in free-stall barn and milking takes place in a parallel type parlor.

This wetland has two vertical beds and a horizontal bed (Sharma et al. 2011). The areas of the vertical flow beds are $160 \mathrm{~m}^{2}$ each and the horizontal bed is $336 \mathrm{~m}^{2}$. The bed dimension and materials are listed in Table 1. The main vegetation that was planted was Phragmites australis. The schematic diagram that describes how the system flows is illustrated in Fig. 1. Feces, urine, non-shippable milk and detergent used to clean the parlor are sent and mixed in the sedimentation tank (underground storage tank). The stored sewage flows into the first vertical bed (VBA) and next to the second vertical bed (VBB). Part of this water is recycled back to the inlet of VBB to increase removal efficiency. The pump for recirculation is equipped with a timer and it is activated every other hour. Then the remaining water from VBB flows into the horizontal bed (HB) and finally the water is released into the environment. There is a set of a pump and a French based self-priming siphon (Molle et al. 2005) at the inlets of VBA and VBB for supplying the water intermittently, and a pump at the inlet of HB. The main bed material for VBA is river gravel, the material for VBB is clinker ash and river gravel, and the material for HB is river sand. Floating material called Supersol(c) is used on the surface of VBA and VBB bed, and autoclaved aerated lightweight concrete (ALC) on HB. They work as insulators to reduce the risk of freezing in winter (Kato et al. 2013). These cover materials and bypass tubes are used in all of the beds to counter clogging issue, which is a problem in all constructed wetlands especially during the startup period (Kato et al. 2013). VBA and VBB are partitioned into two sections so one of the sections could be in a dry phase to facilitate oxidation and drying of the organic layer. The sections are alternately used during growing season.

\section{Methods}

Samples were collected on a monthly to bimonthly basis at the inlet of the system and the outlet of each bed. The samples were tested for TN, ammonia $\left(\mathrm{NH}_{4}-\mathrm{N}\right)$, phosphate $\left(\mathrm{PO}_{4}-\mathrm{P}\right)$, TP, SS, COD, $\mathrm{BOD}_{5}$ and total coliform.

SS was measured by suction filtration method (filtration with pore size of $45 \mu \mathrm{m}$ and drying at $105^{\circ} \mathrm{C}$ ) (APHA et al. 1992). Total coliform was measured using Petrifilm plate count method (APHA et al. 1992). $\mathrm{BOD}_{5}$ was measured by JIS K 0121 method of Japanese Industrial Standards. COD was measured by spectrophotometer (DR2800; Hach, Loveland, CO, USA) using a digital reactor (Hach DRB200) and disposable COD digestion vials (Hach). $\mathrm{NH}_{4}-\mathrm{N}$ was measured using a segmented-flow analysis system (QuAAtro; SEAL Analytical GmbH, Norderstedt, Germany). TN was measured with an elemental analyser (Elementar vario MAX; Elementar Analysensysteme GmbH, Hanau, Germany). TP was measured with a colorimeter using the molybdenum blue ascorbic acid reduction method after decomposition by peroxodisulfate (JIS K0102 46.3.1, Japan).

At the same time, the data from the pressure sensor with data logger (DL/N70; Sensor Technik Sirnach (STS) AG, Sirnach, Switzerland, or S\&DL Mini; Oyo Corp., Tokyo, Japan) placed inside each siphon pit and pump pit were downloaded (Fig. 1). The data logger recorded changes in water level at ten minutes interval. The inflows and the outflows were calculated by the base area of the siphon tank or pump pit multiplied by the changes in water level or by the number of time siphon was activated. The number of times siphon was activated could be counted from the extreme drop in water level. There is a triangular weir to record the outflow of the system, however, proper water level could not be recorded due to the low flow condition and entrapment of garbage, development of biofilm and interference of insects. Thus the outflow of the system was obtained by adding or subtracting evapotranspiration and precipitation multiplied by the bed area to the inflow of HB. Evapotranspiration was calculated using the Penman method and precipitation data were retrieved using a tipping-bucket type rain gauge installed on site or from the local meteorological data (AMeDAS Embetsu Station) provided by Japan Meteorological Agency near the plant. 
Load for all the pollutants were calculated from the concentrations and the flow rates. Average flow rates were calculated between each sampling periods. Both loads and concentrations were quantified in order to determine the full extent of the system in terms of the system's life and also to determine if the system is achieving the regulatory standards. Two efficiency indexes were calculated. First is the purification rate (PR) and this evaluates the removal efficiency in terms of concentration (Eq. 1). Second is the removal rate (RR) and this evaluates the efficiency in terms of load (Eq. 2).

$$
\begin{aligned}
& P R=\left(C_{\text {in }}-C_{\text {out }}\right) / C_{\text {in }} \times 100 \% \\
& R R=\left(M_{\text {in }}-M_{\text {out }}\right) / M_{\text {in }} \times 100 \%
\end{aligned}
$$

Where; $\mathrm{C}_{\text {in }}$ is the influent concentration;

$\mathrm{C}_{\text {out }}$ is the effluent concentration;

$\mathrm{M}_{\text {in }}$ is the influent load; and

$\mathrm{M}_{\text {out }}$ is the effluent load

\section{Results and discussion}

The performance of the system was monitored and evaluated for the six years of its operation. Samples were collected throughout this research $(n=72)$. The summary of the inflow and outflow for each bed is shown in Table 2. The average inflow to the system was $4.8 \mathrm{~m}^{3} /$ day and the average outflow was $5.5 \mathrm{~m}^{3} /$ day. The increase of the system's outflow $\left(0.7 \mathrm{~m}^{3} /\right.$ day) is equal to $1.1 \mathrm{~mm} /$ day (or approximately $389 \mathrm{~mm} /$ year). These numbers are comparable to the overall precipitation subtracted by annual evapotranspiration (PET of $637 \mathrm{~mm} /$ year in 2012 and $590 \mathrm{~mm} /$ year in 2010). Both the inflow and the outflow varied on a daily basis. The maximum inflow and outflow were $35.6 \mathrm{~m}^{3} /$ day and $52.1 \mathrm{~m}^{3} / \mathrm{day}$. On average, $22.2 \mathrm{~m}^{3} /$ day of the effluent of VBB was recycled back in to VBB. The water in this system did not freeze over the winter suggesting that this system works in a cold climate condition even during harsh winter. The recorded lowest atmospheric temperature during the monitoring period was $-24.5^{\circ} \mathrm{C}\left(1^{\text {st }}\right.$ of February 2008) and the average monthly temperature of January and February from 2007 to 2013 were $-6.1^{\circ} \mathrm{C}$ and $-5.4^{\circ} \mathrm{C}$, respectively. The annual snow depth of this region is about $1 \mathrm{~m}$, hence there was a snow cover throughout the winter.

The average influent and effluent concentrations and their associated PR values for this system and for preceding researches are summarized in Table 3. All of the preceding researches explore the ability of constructed wetlands that treat high organic wastewater that are generated from the livestock industries. As of note, the typical concentrations of a domestic sewage are $66 \mathrm{mgCOD} / \mathrm{L}$ and $14 \mathrm{mgSS} / \mathrm{L}$ (Molle et al. 2005). The inflow concentrations were highly dependent on the source of each wastewater and some of them were more concentrated than what Embetsu system was receiving. Generally, our system is comparable or even out performing the other systems, especially in terms of TN, TP and SS. Similar PRs were observed for $\mathrm{NH}_{4}-\mathrm{N}$, COD and $\mathrm{BOD}_{5}$. Although some purification rates could be improved, the average effluent concentrations were satisfying the Japan's discharge standards of $60 \mathrm{mg} / \mathrm{L}$ for TN and $\mathrm{NH}_{4}-\mathrm{N}, 8 \mathrm{mg} / \mathrm{L}$ for TP, $120 \mathrm{mg} / \mathrm{L}$ of $\mathrm{BOD}_{5}$. This is in contrast to the result of the preceding research by Sharma et al. (2013), where $\mathrm{BOD}_{5}$ was not able to achieve the standard at that moment.

The average annual influent and effluent concentrations and the PR for each operation year are illustrated in Fig. 2. For all the pollutants, the influent concentrations of Year 1 were the highest. According to the research done by Sharma et al. (2013), the high influent concentration in Year 1 was caused from the heavy loading of non-shippable milk. Despite the fluctuating influents, the effluent concentrations were relatively stable especially for TP, COD, BOD 5 and SS. For TN, $\mathrm{NH}_{4}-\mathrm{N}, \mathrm{COD}$ and $\mathrm{BOD}_{5}$, the PRs were improving after the second year of its operation. This may have happened because the vegetation has matured enough to provide breeding ground for bacteria that remove and nitrify, and due to the development of plant roots system. Plants also support the removal by transforming the cumulating nutrient in to a gaseous form, mainly through root-zone oxygen release that affects nitrification and denitrification (Tanner 2001). Unlike other contaminants, TP's PRs were generally decreasing from Year 1 and it is certain that the efficiency is decreasing after Year 3. This may be the result of decrease in absorption ability of phosphate because the $\mathrm{PO}_{4}$ - $\mathrm{P}$ has already accumulated in the substrate (Arias et al. 2001; Drizo et al. 1999). Nevertheless, the PR of TP was still close to $70 \%$ after six years of operation thus this system is still acceptable. The purification trend of total coliform is illustrated in Fig. 3. In terms of the number of total coliform, the average annual influent concentrations were in the order of four to six. All the effluents were in the order of two to three and they achieved the regulatory limit of 3,000 total coliform/mL. 
The average influent loads of $\mathrm{TN}, \mathrm{NH}_{4}-\mathrm{N}, \mathrm{TP}, \mathrm{COD}, \mathrm{BOD}_{5}$ and SS for the six years of operation were $1.1 \mathrm{gTN} / \mathrm{m}^{2} /$ day, $0.5 \mathrm{~g} \mathrm{NH}_{4}-\mathrm{N} / \mathrm{m}^{2} /$ day, $0.2 \mathrm{gTP} / \mathrm{m}^{2} /$ day, $26.2 \mathrm{gCOD}(\mathrm{Cr}) / \mathrm{m}^{2} /$ day, $10.0 \mathrm{gBOD} \mathrm{gB}_{5} / \mathrm{m}^{2} /$ day and $4.7 \mathrm{gSS} / \mathrm{m}^{2} /$ day. The average removed loads were $0.9 \mathrm{gTN} / \mathrm{m}^{2} /$ day, $0.4 \mathrm{gNH}_{4}-\mathrm{N} / \mathrm{m}^{2} /$ day, $0.1 \mathrm{gTP} / \mathrm{m}^{2} / \mathrm{day}$, $24.5 \mathrm{gCOD}(\mathrm{Cr}) / \mathrm{m}^{2} /$ day, $9.2 \mathrm{gBOD}_{5} / \mathrm{m}^{2} /$ day and $4.6 \mathrm{gSS} / \mathrm{m}^{2} /$ day. The RRs of $\mathrm{HSCW}$ for these wastewater parameters are summarized in Fig. 4. Similar to the concentration, the loads in Year 1 were high compared to other years. RRs were improving for $\mathrm{TN}, \mathrm{NH}_{4}-\mathrm{N}$ and $\mathrm{BOD}_{5}$, presumably due to the same reason mentioned for PR. TP RR shows a large drop, signifying that the adsorption ability had decreased.

Most pollutants' removal efficiencies for both concentrations and loads were improving in the long term. Especially for $\mathrm{TN}, \mathrm{NH}_{4}-\mathrm{N}$ and $\mathrm{BOD}_{5}$, the trends were evident. According to several studies, the removal efficiencies for matured systems are relatively higher than their startup period. The growth and development of vegetation and associated activity of micro and macroorganisms are playing major roles (Molle 2014) and there are evidences that planted constructed wetlands perform better than the unplanted. This is because the plants root systems provide aeration, inhibits clogging of the bed material by root penetrations and development of bacterial colonies in the rhizomes. In addition, increase in earthworm population is contributing because they are known for its ability to reduce clogging in the organic layer and they are excellent organisms that utilize $\mathrm{BOD}_{5}$. Embetsu's system also contained large population of earthworm especially in VBA (Fig. 5). In addition, the accumulating organic layer improves filtration efficiency, increases water retention time, favors ammonia adsorption onto the layer and promotes biological activity (Molle 2014). Although this system was receiving pollutant at very high concentrations and loads, the same removal mechanisms as HSCW fed with low concentrations and loads were functioning.

The long-term removal efficiency of the phosphorous removal was decreasing. The main mechanisms to remove phosphorus are filtration of particulate phosphorus and adsorption (IWA 2000; Vymazal 2007), thus it is assumable that the removed TP is all attenuated in the system. Hence the system's ability to remove TP was degrading because a lot of phosphate are already attached to the surface of the bed material, thus the ability has decreased (Arias et al. 2001). The cumulative amount of the removed TP is illustrated in Fig. 6. VBA and VBB's TP adsorption are already at their plateau. Removal of TP at VBB was caused partly due to function of clinker ash and this is further described by Drizo et al. (1999). In their experiment, fly ash (in this case, clinker ash) adsorbed approximately $300 \mathrm{mg} / \mathrm{kg}$ of phosphorus in 40 days (fourth out of the seven tested phosphate adsorption substrate), had low bonding capacity $(0.07 \pm 0.01 \mathrm{~g} / \mathrm{kg}$, lowest) but with high adsorption maximum $(0.86 \pm 0.06 \mathrm{~g} / \mathrm{kg}$ highest). However, these numbers should be better than gravels and sand because they lack P adsorption groups such as Fe, Al hydroxide, oxide, and Ca elements on the surface of the substrate.

The performance of each bed is illustrated in Fig. 7. The removal by VBA was exceptionally high for $\mathrm{TN}, \mathrm{COD}, \mathrm{BOD}_{5}$ and $\mathrm{SS}$ and performed less for removal of $\mathrm{NH}_{4}-\mathrm{N}$ and TP. VBA may have performed effectively for TN, SS, COD and $\mathrm{BOD}_{5}$ due to the deposition of organic layer on the surface of the bed. As described by Molle (2014), the deposited organic layer helped filtration efficiency. This layer contributed to removal of large particulate matter and the low permeability allowed the wastewater to be distributed equally on to the surface. The removal rates of $\mathrm{NH}_{4}-\mathrm{N}$ for $\mathrm{VBB}$ were high, presumably due to the recycling of wastewater. The recirculation enhances nitrification and denitrification as noted by Brix and Arias (2005b) and Ayaz et al. (2012). Also, clinker ash neutralized the low pH water and that may have allowed the nitrification to take place.

\section{Conclusion}

The PR and RR of all the pollutants were relatively high after six years of operation. Some removal efficiencies such as $\mathrm{TN}, \mathrm{NH}_{4}-\mathrm{N}, \mathrm{COD}$ and $\mathrm{BOD}_{5}$ were improving. For the past few years, the final effluent load and concentration remained stable even with the fluctuating influents. These improvements may be the result of the formation of organic layer, enhancement of soil ecosystem, active macroorganism such as earthworm and maturation of vegetation that is associated with enriched rhizosphere with flourishing microorganisms. However, the removal of TP is plateaued or even decreasing seemingly because bed material could adsorb less phosphate hence they are not removed from the actual bed. The removal efficiencies by the three beds have some distinct characteristics, such as the RR of TN, COD, $\mathrm{BOD}_{5}$ and SS by VBA were higher than the remaining beds. TP removal by VBB is maintained due to clinker ash layer and $\mathrm{NH}_{4}-\mathrm{N}$ through recirculation of wastewater and neutralization of $\mathrm{pH}$. Although with the degrading TP removal efficiency, this system still had the potential to treat all wastewater parameters at an acceptable level even after its six years of operation. 


\section{Acknowledgements}

We would like to express our sincere appreciation to the Ministry of Agriculture, Forestry and Fisheries, Japan for their financial support and the owner of the dairy farm in Embetsu in order to carry out our research.

\section{References}

American Public Health Association, American Water Works Association, Water Environment Federation (1992) Standard methods for the examination of water and wastewater. American Public Health Association, Washington DC, USA

Arias CA, Bubba MD, Brix H (2001) Phosphorus removal by sands for use as media in subsurface flow constructed reed beds, Water Research. 35 (5); 1159-1168. doi: S0043-1354(00)00368-7

Ayaz SÇ, Aktaş Ö, Findik N, Akça L, Kinaci C (2012) Effect of recirculation on nitrogen removal in a hybrid constructed wetland system. Ecological Engineering. 40; 1-5. doi:10.1016/j.ecoleng.2011.12.028

Brix H, Arias CA (2005a) Danish guidelines for small-scale constructed wetland systems for onsite treatment of domestic sewage. Water Science and Technology. 51(9); 1-9. doi:10.1016/j.ecoleng.2005.07.009

Brix H, Arias CA (2005b) The use of vertical flow constructed wetlands for on-site treatment of domestic wastewater: New Danish guidelines. Ecological Engineering. 25; 491-500.

Carvalho OE, Arajúo JL, Mucha AP, Basto MCP, Almeida CMR (2013) Potential of constructed wetlands microcosms for the removal of veterinary pharmaceuticals from livestock wastewater. Bioresource Technology. 134; 412-416. doi: 10.1016

Comino E, Riggio V, Rosso M (2011) Mountain cheese factory wastewater treatment with the use of a hybrid constructed wetland. Ecological Engineering. 37; 1673-1680. doi:10.1016

Comino E, Riggio V, Rosso M (2013) Constructed wetland treatment of agricultural effluent from an anaerobic digester. Ecological Engineering. 54; 165-172. doi:10.1016

Drizo A, Frost CA, Grace J, Smith KA (1999) Physico-chemical screening of phosphate removing substrates for use in constructed wetland systems. Water Research. 33 (17); 3595-3602. PII: S0043-1354(99)0082-2

Food and Agriculture Organization of the United Nations (2006) Livestock`s Long Shadow. Viale delle Terme di Carcalla, Rome, Italy

IWA Specialist Group on use of Macrophytes in Water Pollution Control (2000) Constructed Wetlands for Pollution Control, Processes, Performance, Design and Operation. IWA Publishing, London, UK

Kato K, Inoue T, Ietsugu H, Sasaki H, Harada J, Kitagawa K, Sharma PK (2013) Design and performance of hybrid constructed wetland systems for high-content wastewater treatment in the cold climate of Hokkaido, northern Japan. Water Science \& Technology. 68.7; 1468-1476. doi: 10.2166/wst2013.3.364

Mantovi P, Marmiroli M, Maestri E, Tagliavini S, Piccinini S, Marmiroli N (2003) Application of a horizontal subsurface flow constructed wetland on treatment of dairy parlor wastewater. Bioresource Technology. 88; 85-94. PII: S0960-8524(02)00291-2

Ministry of Agriculture, Forestry and Fisheries (2014). Status of number of complaints related to livestock industry. http://www.maff.go.jp/j/chikusan/kankyo/taisaku/pdf/kujou22.pdf Accessed 24 June 2014. (in Japanese)

Molle P, Liénard A, Boutin C, Merlin G, Iwema A (2005) How to treat raw sewage with constructed wetlands: an overview of the French systems. Water Science and Technology 51 (9); 11-21

Molle P (2014) French vertical flow constructed wetlands: a need of a better understanding of the role of the deposit layer. Water Science \& Technology. 69.1; 106-112. doi: 102166/ws2013.561

Reeb G, Werckmann M (2005) First performance data on the use of two pilot-constructed wetlands for highly loaded non-domestic sewage. Vymazal (Ed.), Natural and Constructed wetlands nutrients, metals and management, Backhuys Publishers, Leiden, The Netherlands, pp 43-51

Sharma PK, Inoue T, Kato K, Ietsugu H, Tomita K, Nagasawa T (2011) Potential of hybrid constructed wetland system in treating milking parlor wastewater under cold climatic conditions in northern Hokkaido, Japan. Water Practice \& Technology, 6(3)

Sharma PK, Inoue T, Kato K, Ietsugu H, Tomita K, Nagasawa T (2013) Effects of load fluctuations on treatment potential of a hybrid sub-surface flow constructed wetland treating milking parlor waste water. Ecological Engineering. 57; 216-225. doi: 10.1016/j.ecoleng.2013.04.031 
Tanner CC (2001) Plants as ecosystem engineers in subsurface-flow treatment wetlands. Water Science and Technology. 44(11-12); 9-17

Vymazal J (2007) Removal of nutrients in various types of constructed wetlands. Science of the Total Environment. 380; 48-65. doi:10.1016/j.scitotenv.2006.09.014

Vymazal J, Kröpfelová L (2011) A three-stage experimental constructed wetland for treatment of domestic sewage: First 2 years of operation. Ecological Engineering. 37; 90-98. doi:10.1016/j.ecoleng.2010.03.004 


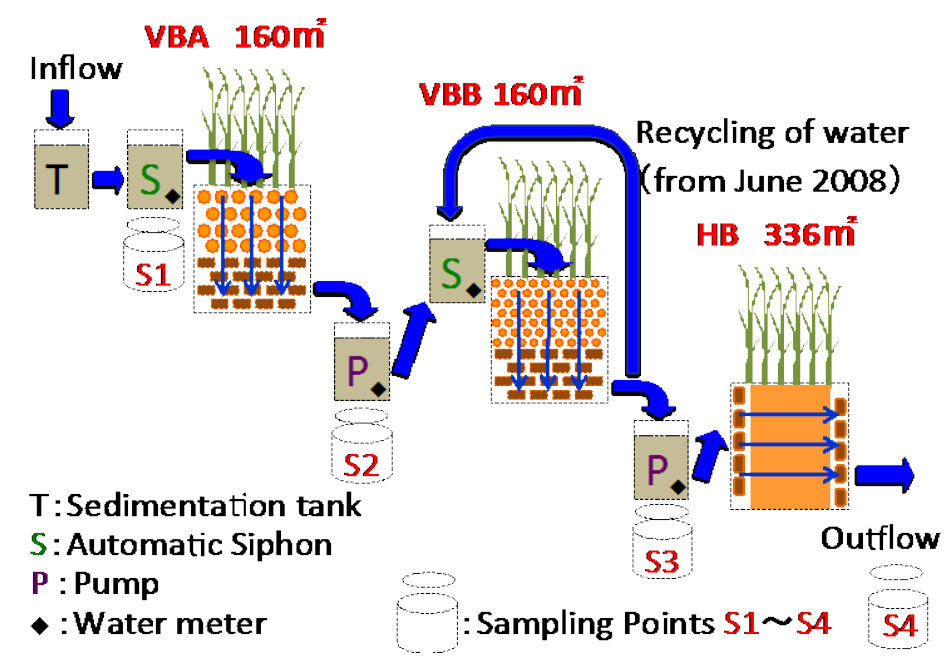

Fig.1. Schematic diagram of the system

Table 1. Bed dimensions and media

\begin{tabular}{cccccc}
\hline Bed & $\begin{array}{c}\text { Area } \\
\left(\mathrm{m}^{2}\right)\end{array}$ & $\begin{array}{c}\text { Average Depth } \\
(\mathrm{m})\end{array}$ & $\begin{array}{c}\text { Volume } \\
\left(\mathrm{m}^{3}\right)\end{array}$ & Bed Material & Cover Material \\
\hline VBA & 160 & 0.75 & 120 & River gravel & Supersol \\
VBB & 160 & 0.71 & 114 & $\begin{array}{c}\text { Clinker ash } \\
\text { River gravel }\end{array}$ & Supersol \\
HB & 336 & 0.72 & 242 & Sand & ALC \\
Total & 656 & - & 476 & - & - \\
\hline
\end{tabular}

Table 2. Hydraulic load of the system

* amount of recycled water

\begin{tabular}{ll}
\hline & Flow $\left(\mathrm{m}^{3} /\right.$ day $)$ \\
\hline Inflow VBA & 4.8 \\
Inflow VBB & $4.9(* 22.2)$ \\
Inflow HB & 4.4 \\
Outflow HB & 5.5 \\
\hline
\end{tabular}



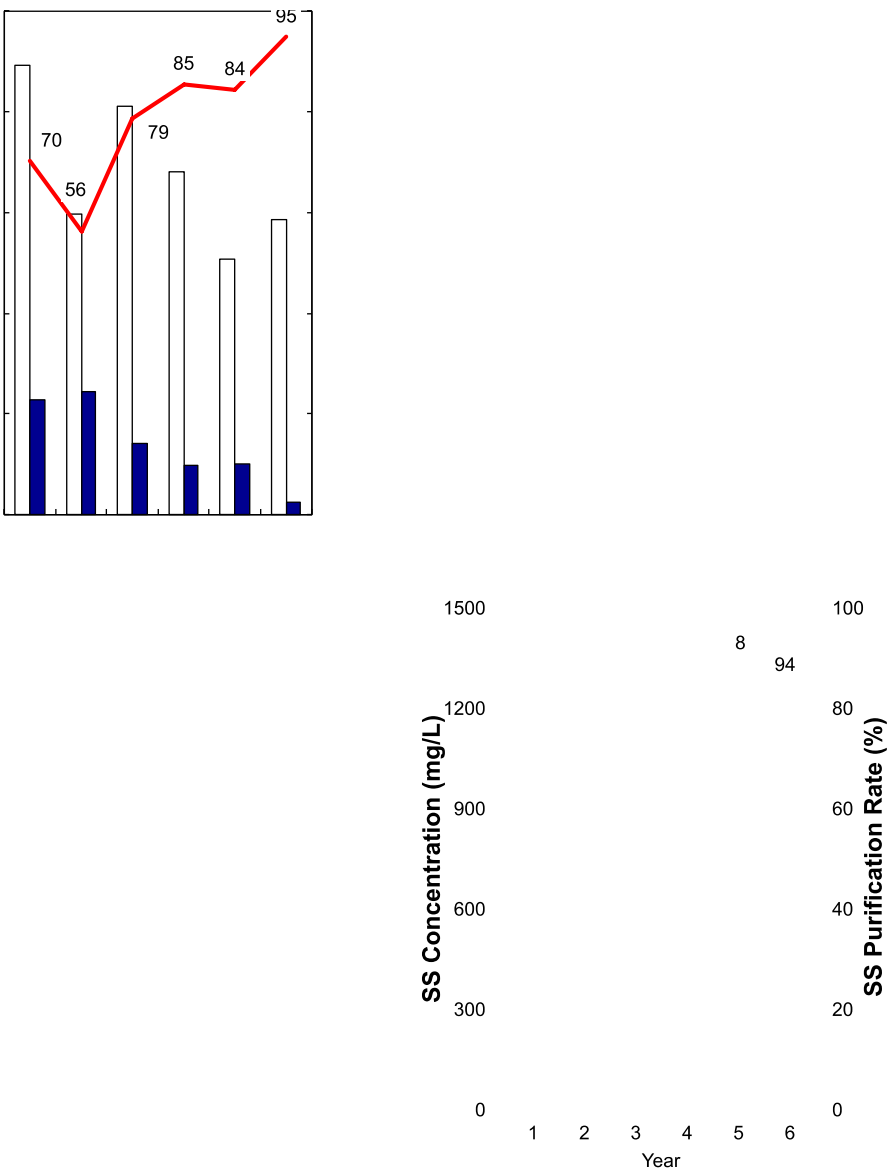

Fig.2. Average annual influent and effluent concentrations and purification rates 


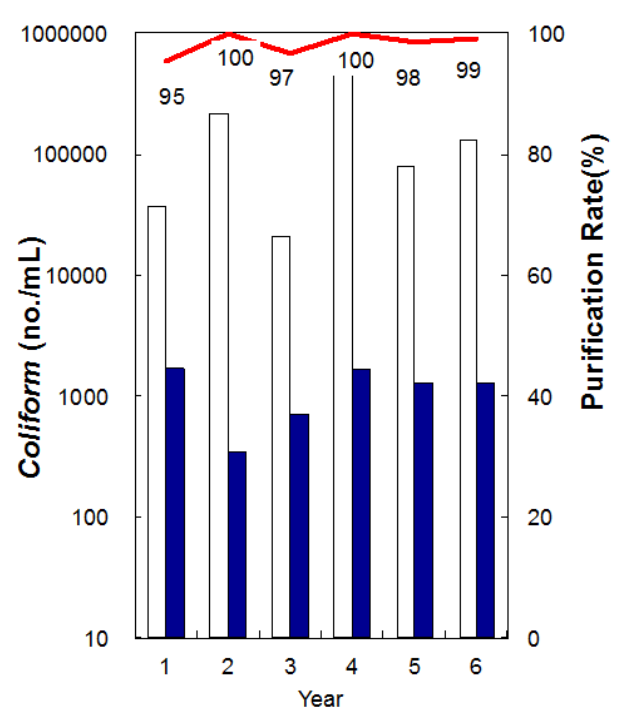

$\square$ Influent $\square$ Effluent -Purification Rate

Fig.3. Average annual influent and effluent

concentrations and purification rates of total coliform

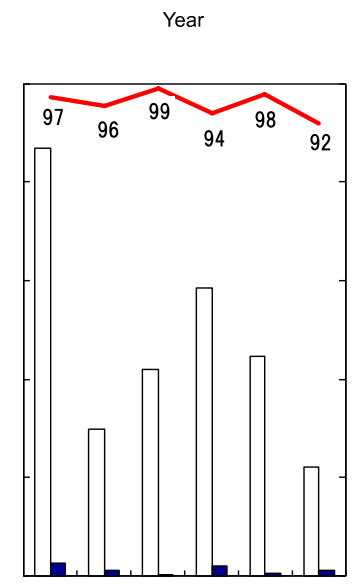

Fig.4. Average annual influent and effluent loads and removal rates 


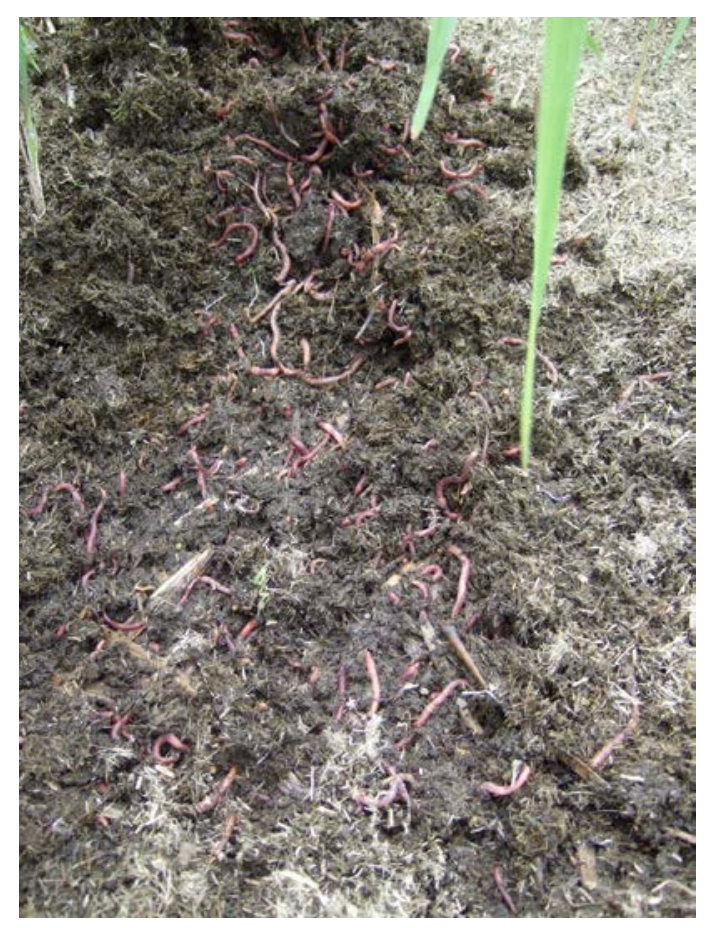

Fig.5. Picture of earthworm in the organic layer of VBA

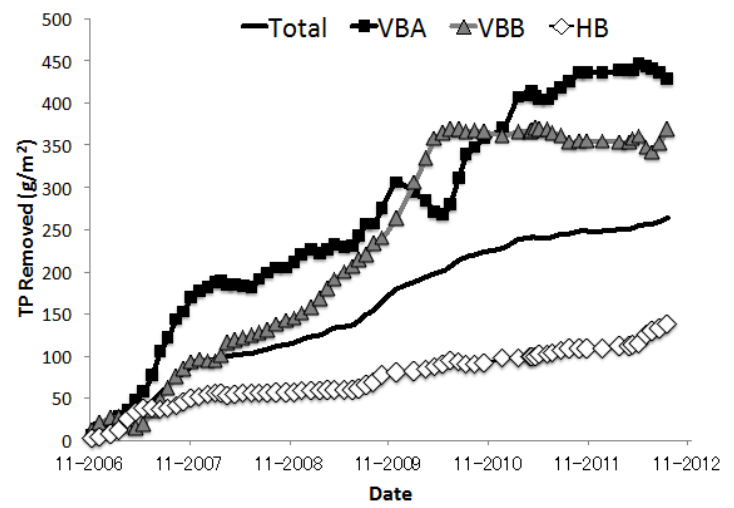

Fig.6. Cumulative TP removed by each bed and the entire system during the operation

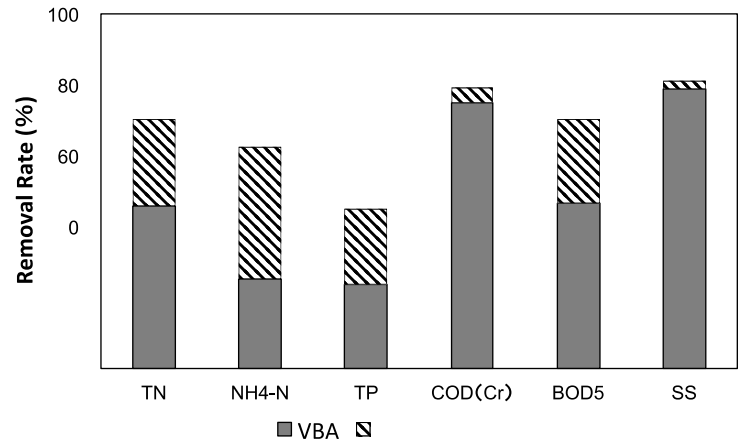

Fig.7. Performance of each bed by removal rate 
Table 3. Inflow and outflow concentrations and their associated purification rates for constructed wetlands that are treating livestock related industry wastewater. a: the experiment with hydraulic loading of 200L/day from an agro-zoo by Comino et al. 2013

b: the experiment done with hydraulic loading of 50L/day wastewater from agro-zoo by Comino et al. 2013

c: only the newest data set (2002 06/11) from the experiment is used

\begin{tabular}{|c|c|c|c|c|c|c|c|c|c|c|c|c|c|c|c|c|c|c|}
\hline & \multicolumn{3}{|c|}{ TN(TKN) } & \multicolumn{3}{|c|}{$\mathrm{NH}_{4}-\mathrm{N}$} & \multicolumn{3}{|c|}{$\mathbf{T P}\left(\mathrm{PO}_{4}-\mathrm{P}\right)$} & \multicolumn{3}{|c|}{ COD } & \multicolumn{3}{|c|}{ BOD $_{5}$} & \multicolumn{3}{|c|}{ SS(TSS) } \\
\hline & $\underset{(\mathrm{mg} / \mathrm{L})}{\mathbf{l n}}$ & $\begin{array}{c}\text { Out } \\
\text { (mg/L) }\end{array}$ & $\begin{array}{l}\text { PR } \\
\text { (\%) }\end{array}$ & $\underset{(\mathrm{mg} / \mathrm{L})}{\mathbf{I n}}$ & $\underset{(\mathrm{mg} / \mathrm{L})}{\text { Out }}$ & $\begin{array}{l}\text { PR } \\
\text { (\%) }\end{array}$ & $\underset{(\mathrm{mg} / \mathrm{L})}{\mathrm{In}}$ & $\underset{(\mathrm{mg} / \mathrm{L})}{\text { Out }}$ & $\begin{array}{l}\text { PR } \\
\text { (\%) }\end{array}$ & $\underset{(\mathrm{mg} / \mathrm{L})}{\mathrm{In}}$ & $\underset{(\mathrm{mg} / \mathrm{L})}{\text { Out }}$ & $\begin{array}{l}\text { PR } \\
\text { (\%) }\end{array}$ & $\underset{(\mathrm{mg} / \mathrm{L})}{\mathrm{In}}$ & $\begin{array}{c}\text { Out } \\
(\mathrm{mg} / \mathrm{L})\end{array}$ & $\begin{array}{l}\text { PR } \\
\text { (\%) }\end{array}$ & $\underset{(\mathrm{mg} / \mathrm{L})}{\mathrm{In}}$ & $\begin{array}{c}\text { Out } \\
\text { (mg/L) }\end{array}$ & $\begin{array}{l}\text { PR } \\
(\%)\end{array}$ \\
\hline Embetsu & 146.3 & 21.4 & 84.9 & 68.5 & 14.3 & 77.5 & 23.6 & 5.2 & 75.5 & $3,611.6$ & 212.3 & 93.5 & $1,393.1$ & 101.2 & 93.3 & 661.8 & 13.5 & 96.9 \\
\hline $\begin{array}{l}\text { Comino et al. } \\
\text { (2011) }\end{array}$ & - & - & - & 3.82 & - & - & 17.37 & - & $\approx 55$ & $2,248.3$ & - & 80 & $1,016.8$ & - & 80 & 504 & - & $\approx 80$ \\
\hline $\begin{array}{c}\text { Comino et al. } \\
(2013)^{\mathrm{a}}\end{array}$ & - & - & - & 130 & 2.4 & 98 & (4) & $(0.02)$ & - & 820 & 95.1 & 88 & - & - & - & - & - & - \\
\hline $\begin{array}{c}\text { Comino et al. } \\
(2013)^{\mathrm{b}}\end{array}$ & - & - & - & 120 & 15.4 & 87 & (44) & (5.56) & - & 1192 & 279.8 & 76.5 & - & - & - & - & - & - \\
\hline $\begin{array}{l}\text { Mantovi et al. } \\
\quad(2003)\end{array}$ & 64.7 & 33.3 & 48.5 & 22.4 & 24.5 & - & 12.8 & 5.0 & 60.6 & 1,219 & 98 & 91.9 & 451 & 28 & 93.7 & $(690)$ & $(60)$ & (90.8) \\
\hline $\begin{array}{c}\text { Reeb and } \\
\text { Werckmann } \\
(2005)^{\mathbf{c}}\end{array}$ & (151.9) & (39.8) & (73.8) & 27.3 & 26.7 & - & 67.7 & 61.3 & - & 4,880 & 566 & 88.5 & 3,780 & 371 & 90.2 & 527 & 58 & 89.0 \\
\hline IWA (2000) & 103 & 51 & 51 & 105 & 42 & 60 & - & - & - & - & - & - & 442 & 141 & 68 & (1111) & (592) & (47) \\
\hline
\end{tabular}

